\title{
Effect of Personality Traits and Contextual Factors on Entrepreneurial Intentions among Undergraduate Students of Nigerian Universities
}

\author{
Bukar Ali Bularafa ${ }^{1^{*}}$ \\ Adamu Isa Gamawa ${ }^{2}$ \\ Centre for Entrepreneurship Development ${ }^{1}$ \\ Department of Business Administration and Management ${ }^{2}$ \\ College of Administration Management and Technology ${ }^{1 \& 2}$ \\ Potiskum, Yobe State Nigeria ${ }^{1 \& 2}$
}

\begin{abstract}
This paper aims to explore the moderating effect of culture on the relationship between personality traits (self-efficacy, risk-taking propensity), contextual factors (university environment, government support) and entrepreneurial intentions among students of universities in North-eastern, Nigeria. The study used survey design, and questionnaire were used for data collection. However, a sample of 383 students was drawn from the population of 118,479 students. Data were analysed using SEM - AMOS. Findings indicate significant relationship and positive effect between risk-taking propensity, selfefficacy, government support programmes and students' entrepreneurial intentions, while no significant relationship and effect found between university environment and students' entrepreneurial intentions. Furthermore, culture has full moderation effect between risk-taking propensity, university environment, government support programmes and students' entrepreneurial intentions, while partial moderation between self-efficacy and students' entrepreneurial intentions. Finally, the study discusses practical implications and directions for future research.

Keywords: personality factors; contextual factors; entrepreneurial intention; university; undergraduate students; Nigeria.
\end{abstract}

*Corresponding author: Bukar Ali Bularafa; Email: abbularafa@gmail.com DOI: https://doi.org/10.37227/JIBM-2021-01-209

\section{Introduction}

Despite the growing attention on the role of entrepreneurship in economic growth, scholars are quietly challenged to clarify precisely why entrepreneurial activity and its effect vary among nations, some countries are more entrepreneurial while others are less entrepreneurial (Stenholm, Acs \& Wuebker, 2013). While certain attention has been keen on understand the determinants of entrepreneurship. Thus they tend not to consider how culture might influence one's entrepreneurial intention. Little empirical research has been undertaken on the effect of culture and the relationship between entrepreneurship determinants and entrepreneurial intentions. Therefore, this study focus on moderating effect of culture on the relationship between self-efficacy, risk-taking propensity, university environment, government support programmes and entrepreneurial intentions among 
graduate students of universities in North-eastern, Nigeria. The paper comprises of six parts; first part form the introduction section, the second part is the literature review, the third part is the methodology, the fourth part of the paper is the results, while the fifth is the discussion part and the sixth part of the paper form the conclusion.

\section{Literature Review}

\section{Entrepreneurial Intention}

In order to understand the concept entrepreneurial intention, first and foremost, it is pertinent to have a clear view of the term entrepreneurship. Various meaning of "entrepreneur or entrepreneurship" found in literature, leading to considerable definitions about the concept. Hence, these definitions are inconsistent due to individual perception and differences in the field of study. However, entrepreneur or entrepreneurship is been define differently depending on individuals or field of study, for instance, Schumpeter (1934) considered entrepreneur to be someone who brings about new things by means of creative destruction, while Leibenstein (1968) defined an entrepreneur as a person who fills vacuum that exists in the marketplace. Bygrave and Hofer (1992) as an individual who sees opportunity and establishes a new business and to take advantage. Furthermore, according to Low and MacMillan (1988) entrepreneurship has been defined as "creation of new enterprise". Entrepreneurship involved change, vision, creation and the ability to see opportunity where others do not see (Kuratko, 2009).

Literature indicates that entrepreneurship begins by identifying opportunity, and the process is surely an intentional process (Wang, $\mathrm{Lu}, \&$ Millington, 2011). The entrepreneurial intention is the conscious state of the mind that will be precursor action which influences the mind in the process of venture formation as a desire (Shane \& Venkataraman, 2000). Entrepreneurial intention predicts students participation in entrepreneurial activities and the reason why they choose to go into business (Ariff, Husna, Bidin, Sharif, \& Ahmad, 2010). Knowing the actual factors responsible for influencing student's intention towards establishing a new business is critical in instituting the policies and programmes that target at encouraging entrepreneurial attitude (Haris, Yahya, Abdullah, Othman, \& Rahman, 2016).

However, many research has been conducted on entrepreneurial intentions in European, American, and Asian nations such as (Athayde, 2012; Nasiru, Keat, \& Bhatti, 2015; Solesvik, Westhead, \& Matlay, 2014), hence, few studies were conducted in Africa, and Nigeria in particular for instance (Ekore \& Okekeocha, 2012; Fatoki, 2014). Therefore, it was found that many personality traits and contextual factors which include; self-efficacy, risk-taking, the locus of control need for achievement, entrepreneurship education, capital, resource, legal framework and infrastructure, and socio-cultural factors could encourage or prevent entrepreneurial behaviour (Turker \& Sonmez Selçuk, 2009). It is imperative to carry out research in Africa, especially Nigeria to understand the factors that affect entrepreneurial intentions so also why some regions are more entrepreneurial while others are less entrepreneurial.

\section{Variables of the Study}

\section{Self-efficacy}

Self-efficacy is a concept came from social learning theory profounded by Bandura. According to Bandura (1977) self-efficacy refers to a person's belief in his cap(ability) to succeed in a given task. The term self-efficacy is linked with entrepreneurial intention and referred as 'entrepreneurial selfefficacy'(ESE). Cromie (2000) expressed that self-efficacy affected individual's beliefs and intentions over time period from their accomplishment in realising individual's objectives. Studies indicate that self-efficacy is a significant variable in choice for an entrepreneurial career. Furthermore, Carr and Sequeira (2007) showed that high self-efficacy results in high entrepreneurial 
intentions. Previous studies indicate significant relationship exists between self-efficacy and student's entrepreneurial intention (Ojewumi, Oyeleke, Agberotimi, \& Adedayo, 2018; Rameseder, 2017; Raza \& Irfan, 2017). In contrast (Apriliana \& Djatmika, 2017; Rasul, Bekun, \& Saint Akadiri, 2017). This inconsistency may be due to cultural variations. Thus the following hypothesis formulated:

H1: There is a significant relationship between self-efficacy and university student's entrepreneurial intentions.

\section{Risk Taking Propensity}

According to Sánchez (2011) risk-taking is a concept that has linked with entrepreneurial activities. Entrepreneurship activity by default involves some sort of risk-taking (Sánchez, 2011). Risk-taking is a necessary variable of entrepreneurship and refers to the ability of a person to show risk-taking or risk averse when faced with conditions that might contain some sort of risk (Gürol \& Atsan, 2006). Furthermore, Brockhaus (1980) 'the propensity for risk-taking is defined as the perceived probability of receiving the rewards associated with success of a proposed situation, which is required by an individual before he will subject himself to the consequences associated with failure, the alternative situation providing less reward as well as less severe consequences than the proposed situation.' Studies indicated that risk-taking propensity is statistically significant in determining students entrepreneurial intention (Chipeta \& Surujlal, 2017; Suffian, Rosman, Norlaila, Norizan, \& Hasnan, 2018). Contrary (Park, 2017). Thus the following hypothesis formulated:

H2: There is a significant relationship between risk-taking propensity and university student's entrepreneurial intentions.

\section{University Environment}

Studies indicate that there is a link between university environment and entrepreneurial intention (Bae, Qian, Miao, \& Fiet, 2014). The inculcated values and norms with the university environment can influence entrepreneurial intentions. Today universities play a great importance in entrepreneurial development such as offering entrepreneurship education to improve entrepreneurship intentions among students (Klofsten, 2000), provision of incubating equipment (Nielsen \& Lassen, 2012), provision of mentoring and networking services (Rothaermel, Agung, \& Jiang, 2007). University environment consists of organisational culture, governance, and leadership, and infrastructure and its manner in the privatisation of research and technology and various types of entrepreneurship resources (Sotirakou, 2004). Other objectives of the universities include promotion of entrepreneurial spirits, encourage the establishment of optimistic beliefs about a career in entrepreneurship among students and promoting the attitude that is necessary for entrepreneurial intention development and achievement. Furthermore, full implementation of activities that geared towards promotion of entrepreneurship in the university brings about conducive environment in terms of entrepreneurial intentions predictors that are linked to subjective norms which can also bring about conducive atmosphere for the transformation of intention to action, as students were encouraged by the people in the university environment to continue with business formation (Shirokova, Osiyevskyy, \& Bogatyreva, 2016)

Franke and Lüthje (2004) in their study discovered that students who evaluate the university environment as conducive to promote entrepreneurial activities will have a high propensity for 
entrepreneurial intentions, but for those students that view the university environment as unconducive for entrepreneurial activities will have a low propensity for entrepreneurial intentions, they compared the effects of personal variables and the university environment and found that university environment was the most influential on entrepreneurial intention. Furthermore, university environment was found to be a significant factor in students choice for entrepreneurial intention (Kolade, 2018; Suffian et al., 2018). Contrary (Belás, Dvorský, Tyll, \& Zvaríková, 2017; Ndofirepi \& Rambe, 2017). Thus the following hypothesis formulated:

H3: There is a significant relationship between university environment and university student's entrepreneurial intentions.

\section{Government Support Programmes}

The recent entrepreneurship development taking place globally as a tool for a job opportunity, economic growth and development were due to many factors among could be government support programmes that were put in place. Provision of the favourable environment which include, infrastructure, legal and institutions, ease of doing business, good government policies and programmes, delivery of training rises entrepreneurial intentions and activities (Martin \& Maabten, 1990). Furthermore, provision of funds, research and training institutions are considered as necessary in promoting quantity of nascent entrepreneurs (Pennings \& Curran, 1982). Previous studies indicate government support programmes have a significant relationship with the entrepreneurial intention (Deshpande, 2018; Suffian et al., 2018). In contrary (Belás et al., 2017).

However, the inconsistency of literature of factors that determine the entrepreneurial intentions and the weak relationship between some predictors and the dependent variable indicates the need for moderating variable as suggested by Baron and Kenny (1986). Thus the following hypothesis formulated:

H4: There is a significant relationship between government support programmes and university student's entrepreneurial intentions.

\section{Moderating Variable}

\section{Culture}

Culture is considered among the external factors that have an influence on individual's entrepreneurial intention, it is often debated that culture played a greater part in influencing entrepreneurial intentions among people (Baughn \& Neupert, 2003). The concept has proved difficult to explain (Ralston, Holt, Terpstra, \& Kai-Cheng, 1997). According to Hofstede, Bond, and Luk (1993), the concept culture is seen as a collection of computing mind that differentiate one class or group of persons from another. Hofstede proposed five cultural dimensions that separate people in a particular country or region (Choe, 2004). Thus: power distance, individualism vs collectivism, uncertainty avoidance, masculinity vs femininity, Confucian dynamism (long term vs short term orientation). Power distance this dimension is related to inequality among people. Hofstede (2001) described power distance as the degree that found between those that in a higher class and those that in lower class together with the level of agreement of that inequality between the culture. In other words, it is the beliefs individuals have regarding the suitability of varied levels of power and right in society. Individualism vs collectivism refers to the degree to which individual's belief about the comparative effect of the person and class to which that individual comes from. Uncertainty avoidance refers to the feeling individuals possess pertaining unknown and ambiguous circumstances. It indicates the position of structure that community thinks and feel relaxed with routine activities. Masculinity vs femininity this refers to the differences among gender in terms of 
goals and aspirations and the separation of feelings. While long-term vs short-term orientation refers to the situation in which individuals are oriented and motivated to work towards future goals and aspirations.

The study adopted Hofstede's cultural dimension because they represent the general attributes of a given culture and also, it is acknowledged by many scholars (Schaubroeck, Lam, \& $\mathrm{Xie}, 2000)$, to measure predicting variables and entrepreneurial intentions among graduate students of universities in North-Eastern, Nigeria. Thus, the following hypotheses were formulated:

H5: There is a moderation effect of culture (power distance, individualism versus collectivism, uncertainty avoidance, masculinity versus femininity, long-term versus short-term orientation) between self-efficacy and university student's entrepreneurial intentions.

H6: There is a moderation effect of culture (power distance, individualism versus collectivism, uncertainty avoidance, masculinity versus femininity, long-term versus short-term orientation) between risk-taking propensity and university student's entrepreneurial intentions.

H7: There is a moderation effect of culture (power distance, individualism versus collectivism, uncertainty avoidance, masculinity versus femininity, long-term versus short-term orientation) between university environment and university student's entrepreneurial intentions.

H8: There is a moderation effect of culture (power distance, individualism versus collectivism, uncertainty avoidance, masculinity versus femininity, long-term versus short-term orientation) between government support programmes and university student's entrepreneurial intentions.

\section{Model of the study}

The theoretical model of the study was based on the Theory of Planned Behaviour (TPB) as one of the best-established theories to predict intentions, including career intentions. There is a growing body of literature arguing that intentions play a very relevant role in the decision to start a new firm. Arbuthnott (2009) exiles the great influence of intention on behaviour as 'the more personal and specific our intention is, the more likely they are to influence our behaviour'. Therefore, it can be deduced that entrepreneurial intention can be decided based on the degree of eagerness and capacity of the person(s) to establish a venture in future. In the model, entrepreneurial intention stands to be the dependent variable and is connected to the independent variables (self-efficacy, risk-taking propensity, university environment and government support programmes) with culture as moderating variables. 


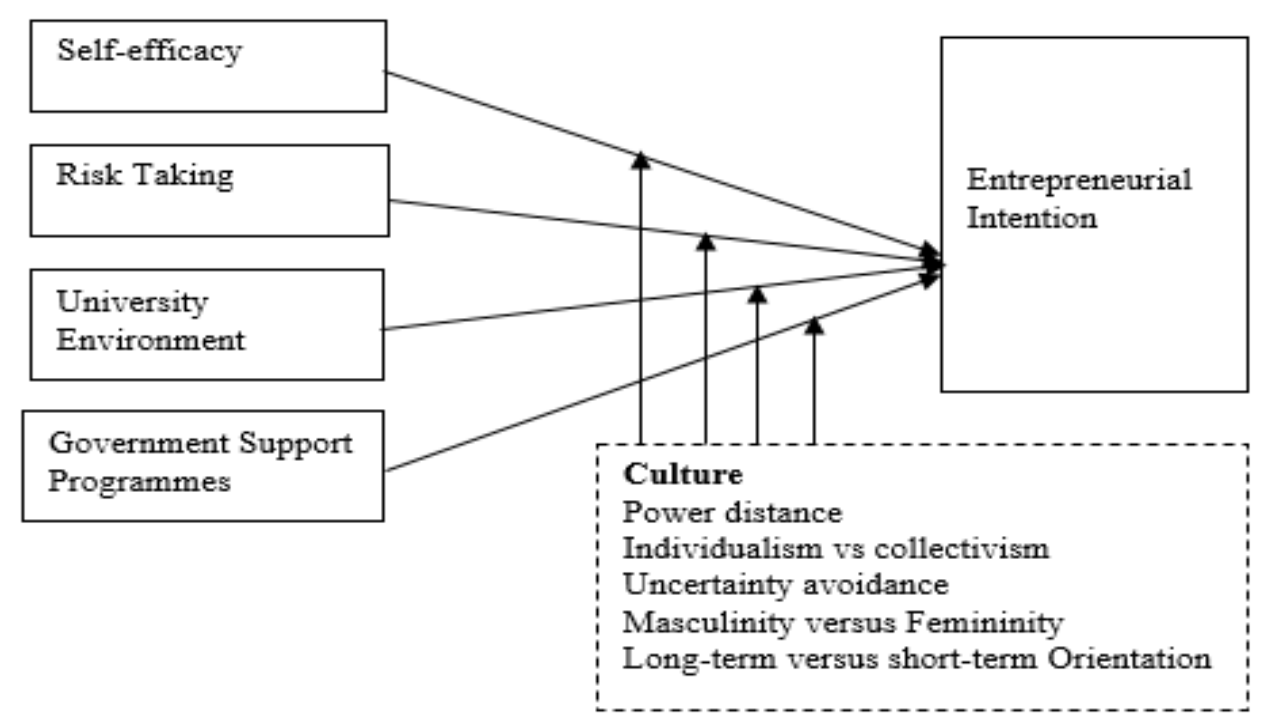

Figure 1 Theoretical Model of the study

\section{Research Methodology}

\section{Participants}

The research design adopted in this study was survey research design. The method of data collection was questionnaire. The population of the study are 118,479 undergraduate students, sample of 383 undergraduate students drawn from three selected faculties, of the three selected universities which comprised of 130 from University of Maiduguri, 119 from Abubakar Tafawa Balewa University Bauchi, and 134 from Modibbo Adama University of Technology Yola, North-Eastern, Nigeria. The sample was selected using systematic sampling procedure. All the 383 questionnaires were filled and returned.

\section{Measures}

The data for the study were solicited through a structured questionnaire, using Likert Scale from 1 Strongly Disagree to 5 Strongly Agree. The source of the instruments were self-efficacy variable having six items adopted from (Shneor, Metin Camgöz, \& Bayhan Karapinar, 2013; Shook \& Bratianu, 2010), risk taking propensity six items adopted from (Mwiya, 2014), university environment ten items adopted from (Saleh \& Salhieh, 2014), government support programmes ten items adopted from (Saleh \& Salhieh, 2014), and moderating variable culture twenty five items comprised of five items on each of five dimensions of power distance (Dunning \& Kim, 2007; Hui, $\mathrm{Au}$, \& Fock, 2004; Jaw, Ling, Yu-Ping Wang, \& Chang, 2007), individualism (Singelis, Triandis, Bhawuk, \& Gelfand, 1995), uncertainty avoidance (Jung \& Kellaris, 2004; Yoon, 2009), masculinity adopted from (Jaw et al., 2007; Yoo, Donthu, \& Lenartowicz, 2011), and long-term orientation adapted from (Yoo et al., 2011), while the dependent variable entrepreneurial intention (EI) with eleven items questionnaire adopted from (Karimi, Biemans, Lans, Mulder, \& Chizari, 2012; Linan, 2008; Mueller Susan, 2011). Prior to that students were given a consent form to indicate their willingness and they were also briefed about the purpose of the study. The administration of the instrument was done by the researcher with the help of three research assistants. Respondents were requested to answer each question by ticking in the appropriate box based on five-point Likert Scale with 1 'strongly disagree, 2 'disagree, 3 'undecided, 4 'agree and 5 'strongly agree. The instrument was tested for reliability using Cronbach Alpha and the reliability obtained was (above .9) which is excellent and acceptable for research instrument. 


\section{Procedure}

The study was based on survey design. Therefore, after an extensive literature review, research hypotheses were formulated, the researcher was able to come up with variables that seem to influenced entrepreneurial intention among university undergraduate students, after then questionnaire was drafted. However, a pilot test was conducted using the drafted questionnaire to confirm if there is any aspect of the instrument that needs to be addressed also to determine the reliability of the instrument. After the pilot test, a final questionnaire was drafted based on the observations from pilot test. The next step in the process is the data collection, the data was collected by the researcher and with the help of three assistants for each university. Data collected were analysed descriptively using SPSS software version 23 and SEM-AMOS. Finally, findings and discussion of the results.

\section{Results and Analysis}

\section{Demographics Factors of the Respondents}

SPSS software version 23 was used to analysed the demographic factors of the respondents, (such as age, marital status, university, parents involved in business, siblings involved in business) and categorised into groups for understanding, gender was categorised into male and female, while faculty (1 Agriculture, 2 Engineering, 3 Management science, 4 Others). Table 4.1 indicates $72 \%$ male and $27.4 \%$ female, and $45.4 \%$ respondents within the age bracket below 25 years old, $44.4 \%$ between age group $20-30$ years old, $10.2 \%$ of the respondents were in age bracket above 30 years old. Furthermore, $68.9 \%$ of respondents were not married, and $24.5 \%$ married while $26.5 \%$ of the respondent either divorced or widowed. Also the analysis shows that $33.9 \%$ respondents from University of Maiduguri, 31.1\% from ATBU and 35\% respondents from MAUTECH, from the Table $14.6 \%$ of the respondents drawn from faculty of Agriculture, $28.2 \%$ from engineering, while $57.2 \%$ of the faculty of management science, the results shows no responses from other faculties.

Table 4.1 Showed Demographic Factors of the Respondents

\begin{tabular}{lll}
\hline Variable & Frequency $(\mathbf{n}=\mathbf{3 8 3})$ & Percentage \\
\hline Male & 278 & 72.6 \\
Female & 105 & 27.4 \\
Age (in years): & & \\
Below 25 years & 174 & 45.4 \\
Between 25 - 30 years & 170 & 44.4 \\
Above 30 years & 39 & 10.2 \\
Marital status: & & \\
Single & 264 & 68.9 \\
Married & 94 & 24.5 \\
others & 25 & 6.5 \\
University & 130 & \\
Maiduguri & 119 & 33.9 \\
ATBU, Bauchi & 134 & 31.1 \\
MAUTECH, Yola & & 35.0 \\
Faculty: & 54 & 14.1 \\
Agriculture & 108 & 28.2 \\
Engineering & 219 & 57.2 \\
Management Science & 00 & 00.0 \\
Others & & \\
Parents involved in business: & 58 & 15.1 \\
Yes, both of them & 110 & 28.7 \\
Yes, one of them & 215 & 56.1 \\
No, none of them & & \\
Siblings involved in business: & 70 & 18.3 \\
Yes, my brother(s) & 106 & 27.7 \\
Yes, my sister(s) & 207 & 54.0 \\
No, none of them & & \\
\hline
\end{tabular}


From the Table above, it shows that $15.1 \%$ of respondents both parents involved in business and $28 \%$ show one of the parents engaged in business, while $56.1 \%$ shows none of the parents involved in business, finally, $18.3 \%$ of respondents revealed his/her brother(s) involved in business, and $27.7 \%$ revealed his/her sister(s) involved in business, while $54.0 \%$ of the respondents indicate none of the siblings were involved in business.

\section{Relationship between the Predictor Variables and Dependent Variable}

Determine the relationship between self-efficacy, risk-taking propensity, university environment, government support programmes and entrepreneurial intention among graduate students four (4) hypotheses were formulated and tested. However, using SEM the output of the structural model was used to ascertain the relationship and effect of the independent variables against the dependent variable. The goodness-of-fit indices are summarised as shown in Table 4.2

Table 4.2 Goodness-of-fit Indices of the Output Structural Model

\begin{tabular}{llllllllll}
\hline Model & CMIN & DF & P & CMIN/DF & IFI & CFI & TLI & GFI & RAMSEA \\
\hline Default Model & 932.856 & 584 & .000 & 1.597 & .982 & .982 & .980 & .891 & .036 \\
Saturated Model & .000 & 0 & & & 1.000 & 1.000 & & 1.000 & \\
Independence Model & 14785.285 & 630 & .000 & 23.469 & .000 & .000 & .000 & .067 & .243 \\
\hline
\end{tabular}

Note: $\mathrm{CMIN}=$ minimum discrepancy (or X2); $\mathrm{DF}=$ degrees of freedom; RAMSEA= root of mean square error of approximation; GFI= goodness-of-fit index; NFI = normed fit index; TLI = TuckerLewis index

Thus, the presentation of the results and discussion of objectives 1and 2 was based on the final output of the structural model as shown in Figure 4.1

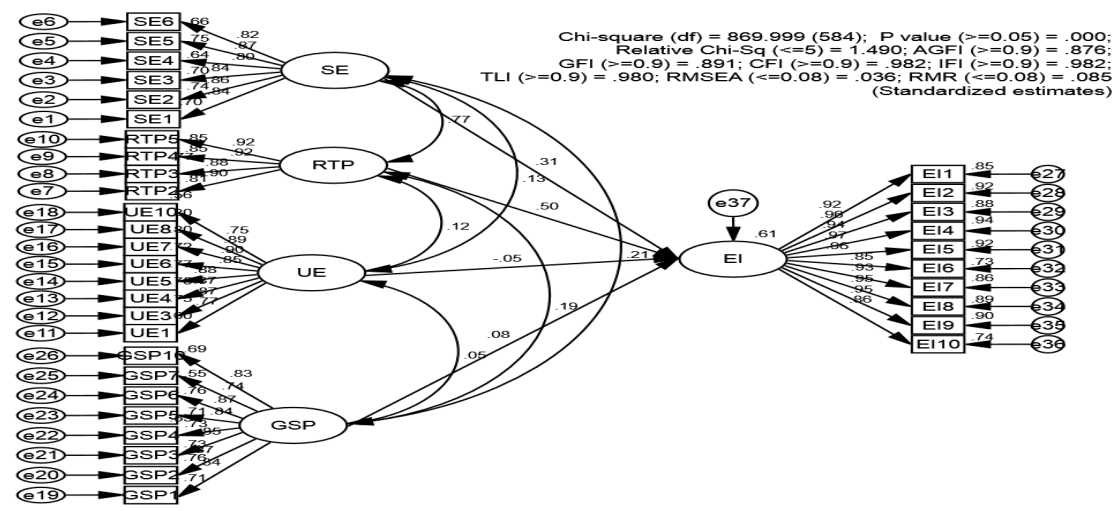

Figure 4.1 Structural Model Output.

Note: $\mathrm{SE}=$ Self-efficacy, RTP $=$ Risk Taking Propensity, UE = University Environment, GSP $=$ Government Support Programmes, EI = Entrepreneurial Intention.

In this section, four (4) hypotheses that were formulated and tested based on objectives one (1) to show the relationship between independent variables (self-efficacy, risk-taking propensity, university environment, government support programmes) and the dependent variable (entrepreneurial intention). Summary of ' $r$ ' coefficients and of the $\beta$ coefficient estimates are depicted in Table 4.3 and 4.4.

Table 4.3 'r' Coefficients between Exogenous Variables and Endogenous Variable

\begin{tabular}{|c|c|c|c|c|}
\hline Construct & Estimate & S.E. & C.R & $\mathbf{P}$ \\
\hline Entrepreneurial intention <--- Risk taking propensity & .539 & .066 & 8.205 & .000 \\
\hline Entrepreneurial intention $<---$ Self-efficacy & .348 & .069 & 5.075 & .000 \\
\hline Entrepreneurial intention <--- University environment & -.081 & .060 & -1.353 & .176 \\
\hline Entrepreneurial intention <--- Government support Programmes & .106 & .045 & 2.353 & .019 \\
\hline
\end{tabular}


The result indicates significant relationship exist between risk taking, self-efficacy and government support programmes and entrepreneurial intention the hypothesis was supported $(\mathrm{r}=.539, p=.000$; $\mathrm{r}=.348, \mathrm{p}=.000$ and $\mathrm{r}=.106, \mathrm{p}=.019)$, while university environment the findings indicates not significant with entrepreneurial intention.

\section{Effect of Predictors on the Dependent variable}

Determine the effect of self-efficacy, risk-taking propensity, university environment, government support programmes on entrepreneurial intention.

Table 4.4 Unstandardized, Standardized Regression Path Coefficients and its Significance based on p-value $<0.05$ from the output of the Structural Model

\begin{tabular}{|l|l|l|l|l|l|}
\hline Construct Path Construct & B & $\boldsymbol{\beta}$ & S.E. & C.R & P \\
\hline Entrepreneurial intention <--- Risk taking propensity & .539 & .498 & .066 & 8.205 & .000 \\
\hline Entrepreneurial intention <--- Self-efficacy & .348 & .308 & .069 & 5.075 & .000 \\
\hline Entrepreneurial intention <--- University environment & -.081 & -.047 & .060 & -1.353 & .176 \\
\hline Entrepreneurial intention <--- Gov't. support programmes & .106 & .083 & .045 & 2.353 & .019 \\
\hline
\end{tabular}

Table 4.4 above indicate there is a significant and positive effect between risk-taking at $p=.00$, selfefficacy $\mathrm{p}=.000$ and government support programmes at .019 , while university environment shows no effect on entrepreneurial intention. Furthermore, the overall effect of a predictor variable on the outcome variable shows all the predictors account for a total of 61 percent variance of the variance in entrepreneurial intentions.

\section{Moderation Effect of Culture on the Relationship between the Independent Variables and Dependent Variable}

Moderating effect of power distance in the relationships between self-efficacy, university environment and government support programmes and entrepreneurial intention. Four hypothesis was formulated and tested to determine the presence of the moderation effect on the overall model, which provide the basis for a subsequent test or otherwise. To test for this hypothesis, the structural modelling output of two models (high and low power distance) was used in the comparison, using multi-group analysis and the summarise structural output results of the moderation effect of power distance on the overall model shown in Table 4.5

Table 4.5 moderation test of power distance on the relationships between self-efficacy, risk-taking propensity, university environment, government support programmes and entrepreneurial intention among graduate students.

\begin{tabular}{lccc}
\hline Model & CMIN $\left(\mathbf{x}^{2}\right)$ & DF & $\boldsymbol{P}$ \\
\hline Unconstrained & 1554.657 & 1168 & .000 \\
Measurement Residuals & 2184.141 & 1250 & .000 \\
Change & 629.484 & 82 & .000 \\
\hline
\end{tabular}

From the comparison output between unconstrained $x^{2}(\mathrm{CMIN})$ and measurement residuals as depicted in Table 4.5, based on the $\Delta x^{2}(\mathrm{CMIN})=629.484 ; \Delta \mathrm{df}=82 ; P=.000$, it shows there is a form of moderation effect of power distance. Therefore, further analysis to determine specific path moderation effect is necessary (Hair, Black, Babin, Anderson, \& Tatham, 2010). The presence of moderation in the overall model provides the additional basis for formulating four (4) specific path hypotheses and tested as depicted in Table 4.5. Moreover, figure 4.2 shows the multi-group structural relationships of power distance models used in testing the moderation. 


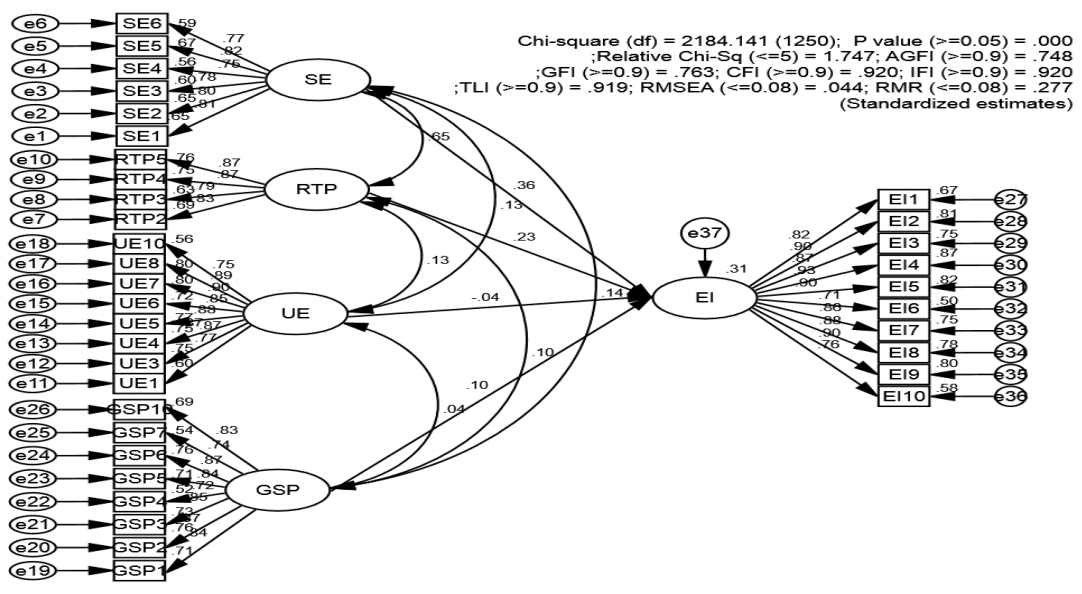

Figure 4.2 Multi Group Structural Moderation Output of Power Distance

Table 4.6 individual path moderation test for power distance on the relationships between self-efficacy, risk-taking propensity, university environment, government support programmes and entrepreneurial intentions.

\begin{tabular}{lllll}
\hline \multicolumn{1}{c}{ Construct } & Path & \multicolumn{1}{c}{ Construct } & B & P \\
\hline Low power distance Standardised & & & \\
Coefficients & & & .187 & .057 \\
Entrepreneurial intention & $<---$ & Risk-taking Propensity & .197 & .038 \\
Entrepreneurial intention & $<---$ & Self-efficacy & -.016 & .821 \\
Entrepreneurial intention & $<---$ & University environment & .044 & .526 \\
Entrepreneurial intention & $<---$ & Gov't. support programmes & & \\
High power distance Standardised & & & .183 & .055 \\
Coefficients & & & .479 & .000 \\
Entrepreneurial intention & $<---$ & Risk-taking Propensity & -.044 & .485 \\
Entrepreneurial intention & $<---$ & Self-efficacy & .109 & .096 \\
Entrepreneurial intention & $<---$ & University environment & \\
Entrepreneurial intention & $<---$ & Gov't. support programmes & & \\
\hline
\end{tabular}

The structural output shows power distance shows partial moderation effect between self-efficacy, while no moderation effect between risk-taking, university environment, and government support programmes.

Table 4.7 moderation test of individualism versus collectivism on the relationships between selfefficacy, risk-taking propensity, university environment, government support programmes and entrepreneurial intention among graduate students.

\begin{tabular}{lccc}
\hline Model & CMIN $\left(\mathbf{x}^{2}\right)$ & DF & $\boldsymbol{P}$ \\
\hline Unconstrained & 1578.282 & 1168 & .000 \\
Measurement Residuals & 2176.855 & 1250 & .000 \\
Change & 598.573 & 82 & .000 \\
\hline
\end{tabular}

From the comparison output between unconstrained $x^{2}(\mathrm{CMIN})$ and measurement residuals as depicted in Table 4.7 based on the $\Delta x^{2}(\mathrm{CMIN})=598.573 ; \Delta \mathrm{df}=82 ; P=.000$, it shows there is a form of moderation effect of individualism versus collectivism, specific path hypotheses and tested as depicted in Table 4.7. Moreover, figure 4.3 shows the multi-group structural relationships of individualism versus collectivism models used in testing the moderation. 


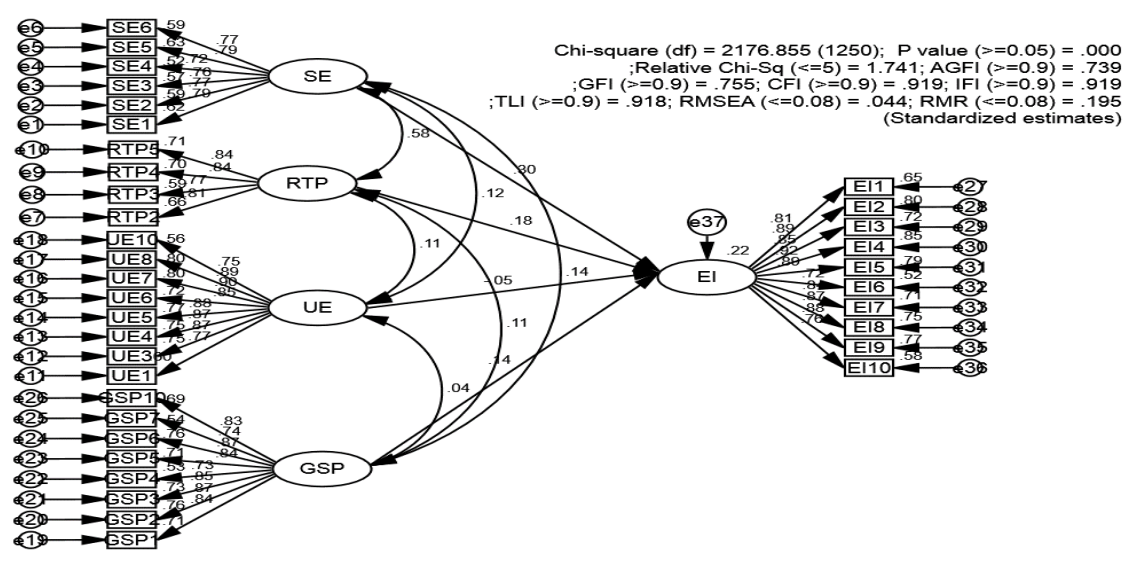

Figure 4.3 Multi Group Structural Moderation Output of Individualism versus Collectivism

Table 4.8 individual path moderation test for individualism versus collectivism on the relationships between self-efficacy, risk-taking propensity, university environment, government support programmes and entrepreneurial intentions.

\begin{tabular}{lllcc}
\hline \multicolumn{1}{c}{ Construct } & Path & \multicolumn{1}{c}{ Construct } & $\boldsymbol{\beta}$ & P \\
\hline Collectivism Standardised Coefficients & & & & \\
Entrepreneurial intention & $<---$ & Risk-taking Propensity & .182 & .072 \\
Entrepreneurial intention & $<---$ & University environment & -.031 & .665 \\
Entrepreneurial intention & $<---$ & Gov't. support programmes & .139 & .067 \\
Entrepreneurial intention & $<---$ & Self-efficacy & .360 & .000 \\
Individualism Standardised Coefficients & & & & .141 \\
Entrepreneurial intention & $<---$ & Risk-taking Propensity & .131 & .141 \\
Entrepreneurial intention & $<---$ & University environment & -.059 & .385 \\
Entrepreneurial intention & $<---$ & Gov't. support programmes & .124 & .064 \\
Entrepreneurial intention & $<---$ & Self-efficacy & .245 & .005 \\
\hline
\end{tabular}

The structural output shows individualism versus collectivism show partial moderation in the relationship self-efficacy and entrepreneurial intention and did not moderate between risk-taking, university environment, and government support programmes.

Table 4.9 moderation test of uncertainty avoidance on the relationships between self-efficacy, risktaking propensity, university environment, government support programmes and entrepreneurial intention among graduate students.

\begin{tabular}{lccc}
\hline Model & CMIN $\left(\mathbf{x}^{2}\right)$ & DF & $\boldsymbol{P}$ \\
\hline Unconstrained & 1608.038 & 1168 & .000 \\
Measurement Residuals & 2179.593 & 1250 & .000 \\
Change & 571.555 & 82 & .000 \\
\hline
\end{tabular}

From the comparison output between unconstrained $x^{2}$ (CMIN) and measurement residuals as depicted in Table 4.9, based on the $\Delta x^{2}(\mathrm{CMIN})=571.555 ; \Delta \mathrm{df}=82 ; P=.000$, it shows there is a form of moderation effect of uncertainty avoidance, further analysis to determine specific path moderation effect is necessary. 


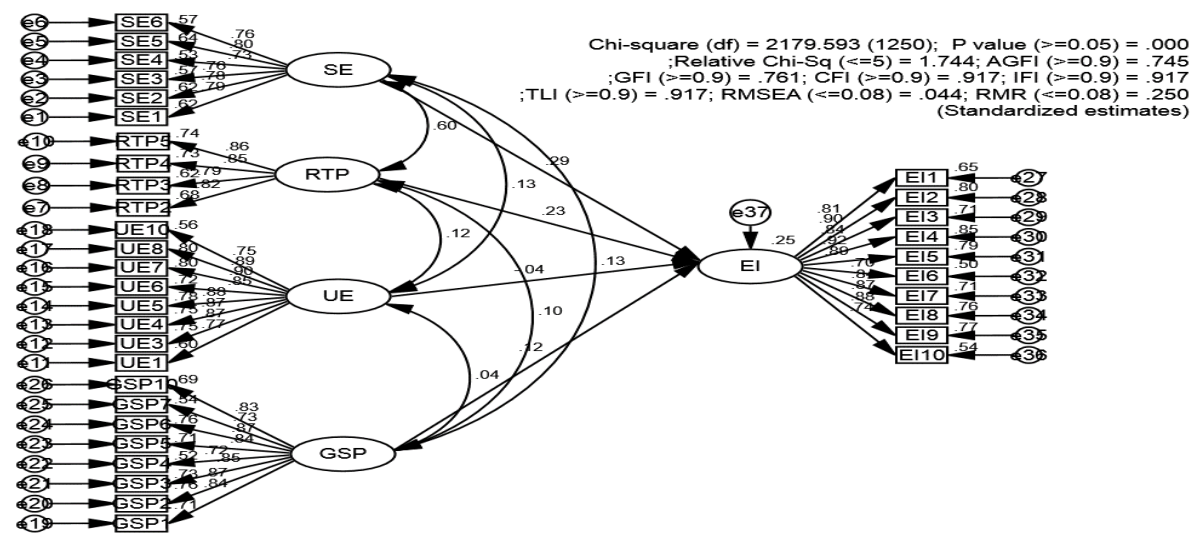

Figure 4.4 Multi Group Structural Moderation Output of Uncertainty Avoidance

Table 4.10 individual path moderation test for uncertainty avoidance on the relationships between self-efficacy, risk-taking propensity, university environment, government support programmes and entrepreneurial intentions.

\begin{tabular}{lllll}
\hline \multicolumn{1}{c}{ Construct } & Path & \multicolumn{1}{c}{ Construct } & B & P \\
\hline Low uncertainty avoidance Standardised & & & \\
Coefficients & & & .039 & .670 \\
Entrepreneurial intention & $<---$ & Risk-taking Propensity & .097 & 197 \\
Entrepreneurial intention & $<---$ & University environment & .040 & .570 \\
Entrepreneurial intention & $<---$ & Gov't. support programmes & .187 & .037 \\
Entrepreneurial intention & $<---$ & Self-efficacy & \\
High uncertainty avoidance & Standardised & & & .239 \\
Coefficients & & & -077 & .245 \\
Entrepreneurial intention & $<---$ & Risk-taking Propensity & .015 \\
Entrepreneurial intention & $<---$ & University environment & .034 \\
Entrepreneurial intention & $<---$ & Gov't. support programmes & .149 \\
Entrepreneurial intention & $<---$ & Self-efficacy & .364 & .000 \\
\hline
\end{tabular}

The structural output indicates a full moderation effect on risk-taking, government support and a partial moderation effect on self-efficacy and entrepreneurial intention.

Table 4.11 Moderation test of masculinity versus femininity on the relationships between selfefficacy, risk-taking propensity, university environment, government support programmes and entrepreneurial intention among graduate students.

\begin{tabular}{lccc}
\hline Model & CMIN $\left(\mathbf{x}^{2}\right)$ & DF & $\boldsymbol{P}$ \\
\hline Unconstrained & 1585.401 & 1168 & .000 \\
Measurement Residuals & 2092.718 & 1250 & .000 \\
Change & 503.317 & 82 & .000 \\
\hline
\end{tabular}

From the comparison output between unconstrained $x^{2}$ (CMIN) and measurement residuals as depicted in Table 4.11, based on the $\Delta x^{2}(\mathrm{CMIN})=503.317 ; \Delta \mathrm{df}=82 ; P=.000$, indicates a form of moderation of masculinity versus femininity in the relationships. 


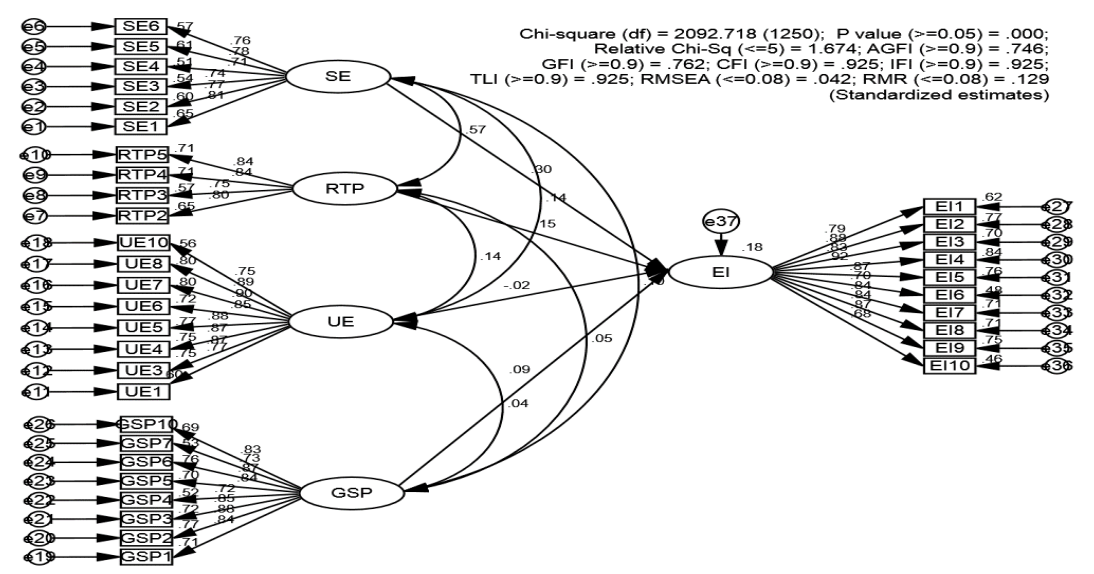

Figure 4.5 Multi Group Structural Moderation Output of Masculinity versus Femininity

Table 4.12 Individual path moderation test for masculinity versus femininity on the relationships between self-efficacy, risk-taking propensity, university environment, government support programmes and entrepreneurial intentions.

\begin{tabular}{lllcc}
\multicolumn{1}{c}{ Construct } & Path & \multicolumn{1}{c}{ Construct } & $\boldsymbol{\beta}$ & P \\
\hline Femininity Standardised Coefficients & & & & \\
Entrepreneurial intention & $<---$ & Risk-taking Propensity & .111 & .287 \\
Entrepreneurial intention & $<---$ & University environment & -.015 & .855 \\
Entrepreneurial intention & $<---$ & Gov't support programmes & .139 & .088 \\
Entrepreneurial intention & $<---$ & Self-efficacy & .402 & .000 \\
Masculinity Standardised Coefficients & & & & .026 \\
Entrepreneurial intention & $<---$ & Risk-taking Propensity & .03 & .554 \\
Entrepreneurial intention & $<---$ & University environment & -.038 & .522 \\
Entrepreneurial intention & $<---$ & Gov't support programmes & .041 & .215 \\
Entrepreneurial intention & $<---$ & Self-efficacy & .012 \\
\hline
\end{tabular}

The structural output indicates a full moderation of masculinity versus femininity between risk-taking and entrepreneurial intention and a partial moderation between self-efficacy and entrepreneurial intentions.

Table 4.13 Moderation test of long-term versus short-term orientation on the relationships between self-efficacy, risk-taking propensity, university environment, government support programmes and entrepreneurial intention among graduate students.

\begin{tabular}{lccc}
\hline Model & CMIN $\left(\mathbf{x}^{2}\right)$ & DF & $\boldsymbol{P}$ \\
\hline Unconstrained & 1591.058 & 1168 & .000 \\
Measurement Residuals & 2057.495 & 1250 & .000 \\
Change & 465.942 & 82 & .000 \\
\hline
\end{tabular}

From the comparison output between unconstrained $x^{2}$ (CMIN) and measurement residuals as depicted in Table 4.13, based on the $\Delta x^{2}(\mathrm{CMIN})=465.942 ; \Delta \mathrm{df}=82 ; P=.000$, it shows there is a form of moderation effect of long-term orientation versus short-term orientation in the relationships. 


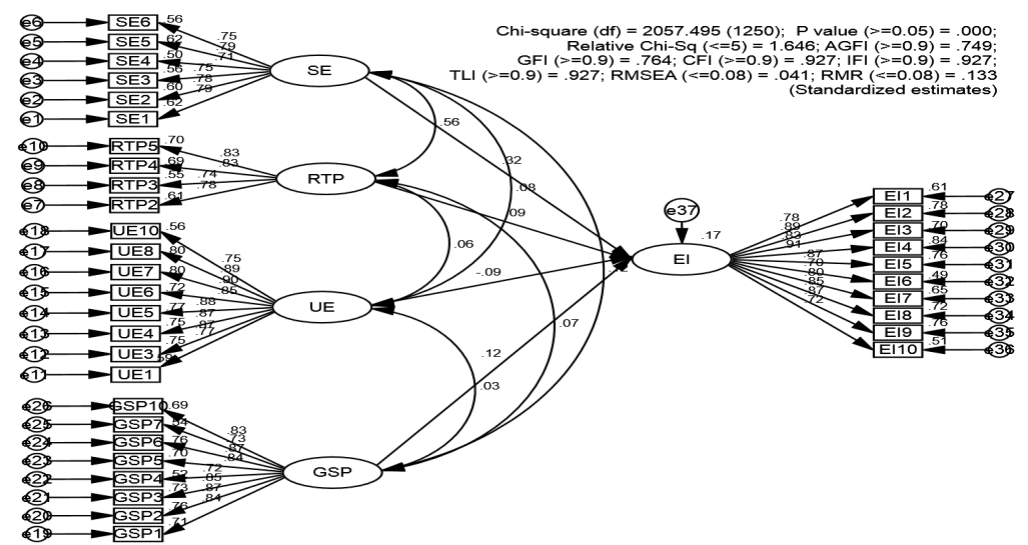

Figure 4.6 Multi Group Structural Moderation Output of Long-term versus Short-term Orientation

Table 4.14 Individual path moderation test for long-term versus short-term orientation on the relationships between self-efficacy, risk-taking propensity, university environment, government support programmes and entrepreneurial intentions.

\begin{tabular}{lllll}
\hline \multicolumn{1}{c}{ Construct } & Path & \multicolumn{1}{c}{ Construct } & $\beta$ & P \\
\hline Short-term orientation Standardised & & & \\
Coefficients & & & -.063 & .522 \\
Entrepreneurial intention & $<---$ & Risk-taking Propensity & -.211 & .009 \\
Entrepreneurial intention & $<--$ & University environment & .150 & .074 \\
Entrepreneurial intention & $<---$ & Gov't support programmes & .401 & .000 \\
Entrepreneurial intention & $<---$ & Self-efficacy & & \\
Long-term orientation Standardised & & & .269 & .003 \\
Coefficients & & & .012 & .848 \\
Entrepreneurial intention & $<---$ & Risk-taking Propensity & .085 & .163 \\
Entrepreneurial intention & $<---$ & University environment & .202 & .021 \\
Entrepreneurial intention & $<---$ & Gov't support programmes & Self-efficacy & \\
Entrepreneurial intention & $<---$ & S & & \\
\hline
\end{tabular}

The structural output indicates a full moderation effect of long-term versus short-term orientation between risk-taking, university environment and a partial moderation effect between self-efficacy and entrepreneurial intention.

\section{Discussion}

The results of this study indicate that most of the respondents were male with $72.6 \%$ as against female counterpart with $27.4 \%$ this is consistent with (Gwija, Chuks, \& Chux, 2014), also, respondents age below 25 years are the majority $45.4 \%$, then respondents age $26-30$ years $44.4 \%$ and age above 30 years $10.2 \%$ similar to studies (Keat \& Ahmad, 2012) furthermore, the study indicate $68.9 \%$ not married (single), and $24.5 \%$ were married, while divorced or widowed constituted $6.5 \%$ indicating majority are not married, this agreed with (Juračak \& Tica, 2016), also, the findings indicate most are from faculty of management science $57.2 \%$ then engineering $28.2 \%$, and Agriculture $14.1 \%$. However, the study's findings also, indicates respondents none of the parents involved in business form majority $56.1 \%$, then one parent involved in business $28.8 \%$, and those with both parents involved in business $15.1 \%$, indicating majority of the respondents none of parents involved in business, this collaborates (Gwija et al., 2014; Marques, Ferreira, Gomes, \& Gouveia Rodrigues, 2012), while respondents none of their siblings involved in business $54 \%$, were majority, then those sisters involved in business $27.7 \%$, and those brother involved in business $18.3 \%$ this line with (Marques et al., 2012).

Furthermore, the findings show a significant relationship and positive effect between risktaking propensity $(\mathrm{p}=.000)$, self-efficacy $(\mathrm{p}=.000)$ and government support programmes $(\mathrm{p}=.019)$, while no significant relationship and negative effect between university environment $(p=.176)$ and students entrepreneurial intention. 
However, overall findings showed there is a form of moderation effect of culture in the relationship between the independent variables and the dependent variable, but specifically, a full moderation of uncertainty avoidance exist between risk-taking propensity (low $\mathrm{p}=.670 ; \mathrm{p}=$ high .015 ), government support programmes (low $\mathrm{p}=.570$; high $\mathrm{p}=.034$ ) and students entrepreneurial intentions, a full moderation of masculinity versus femininity exist between risk-taking propensity (femininity $\mathrm{p}=$ .287 ; masculinity $\mathrm{p}=.026$ ) and students entrepreneurial intentions, contrary to the findings (Mueller, Thomas, \& Jaeger, 2002). Also, full moderation exist of long-term versus short-term orientation between university environment (short-term orientation $p=.009$; long-term orientation $p=.848$ ) this is consistent with the studies (Ali, Yilmaz, \& Ahmed, 2011), and risk-taking propensity (short-term orientation $\mathrm{p}=.522$; long-term orientation $\mathrm{p}=.003$ ). In addition, partial moderation of all the cultural dimensions exist between self-efficacy and student's entrepreneurial intention.

\section{Conclusion}

Entrepreneurship is now dominant and tool in reducing unemployment, poverty reduction, wealth creation and promoting economic growth and development in all facet of economies. This concern attributed as a result of high unemployment, higher inflation, and recession suffered by many countries of the world. Therefore, this situation raises the importance attached to entrepreneurs (Garavan \& $\mathrm{O}^{\prime}$ Cinneide, 1994) as could be a possible remedy to the problems encountered by most nations because the increase rate of entrepreneurship could lead to employment opportunities thereby decreasing joblessness in the society (Hyder, Azhar, Javaid, \& Rehman, 2011). Using data from University of Maiduguri, ATBU, and MAUTECH, SEM-AMOS was used for the analysis, it was revealed that self-efficacy, risk-taking propensity, and government support programmes are significant predictors of entrepreneurial intentions. Overall the results indicate the model fits the data well, which has significant implications for policymakers and other stakeholders that desired to promote entrepreneurial spirit among university graduate students in Nigeria. Personality traits such as self-efficacy, risk-taking propensity and contextual factor such as government support programmes should be given more attention since they have direct positive and significant effect on the entrepreneurial intention of the respondents. Also, cultural dimensions such as uncertainty avoidance, masculinity versus femininity and long-term versus short-term orientation should receive attention as they have a moderating effect on the relationship between all the variables and entrepreneurial intentions of the respondents, though the moderating effect for self-efficacy was partial, but found in all the dimensions. The paper recommends that studies need to be conducted in another region of Nigeria in order to test the results' robustness (Gelderen et al., 2008). Also, crosssectional studies between universities and other tertiary institutions would similarly depict the actual outcome of behavioural intention towards entrepreneurship among Nigerian graduates.

\section{Research Limitation and Future Direction}

Though, the study covers fourteen universities in North-Eastern Nigeria, the data collection was limited to three universities, which can be justified by the number of undergraduate enrolment and number of graduates during the academic session under review. Hence, with the data covering only three universities, and three faculties, the findings of this study may be limited to North-Eastern Nigeria alone. Thus, it may not be generalised or apply to other parts or nations (Fayolle \& Liñán, 2014; Hoskisson, Covin, Volberda, \& Johnson, 2011). The second limitation is that the current research is cross-sectional which shows that the findings may be for only a particular time period, and may therefore, not be applicable over a generalised time period. The third limitation of this study is with regard to the subjects of the study. The data used for the study was obtained from undergraduate students of universities and, therefore, the findings may not be representative of nonstudent's populations. The study will add to available knowledge if future researchers investigate different universities with different categories of respondents. 


\section{Acknowledgement}

The author wishes to acknowledge the managements of the stated universities in North-Eastern Nigeria for giving him the necessary support, and the participants for their patience in filling the questionnaire as required. Also, the author wishes to thank Mr. Gabriel Yamoah for his tireless effort in proofreading the manuscripts.

\section{References}

Ali, I., Yilmaz, A. K., \& Ahmed, S. (2011). Effects of national culture on development of entrepreneurial intentions. Elixir Management Arts, 39(2011), 4622-4626.

Apriliana, A., \& Djatmika, E. T. (2017). Effect of student participation in business center, parent's role, and self-efficiency to entrepreneurship intention students of SMK. Jurnal Pendidikan Bisnis dan Manajemen, 3(3), 167-178.

Arbuthnott, K. D. (2009). Education for sustainable development beyond attitude change. International Journal of Sustainability in Higher Education, 10(2), 152-163.

Ariff, M., Husna, A., Bidin, Z., Sharif, Z., \& Ahmad, A. (2010). Predicting entrepreneurship intention among Malay university accounting students in Malaysia. UNITAR e-Journal, 6(1), 1-10.

Athayde, R. (2012). The impact of enterprise education on attitudes to enterprise in young people: An evaluation study. Education and Training, 54(8/9), 709-726.

Bae, T. J., Qian, S., Miao, C., \& Fiet, J. O. (2014). The relationship between entrepreneurship education and entrepreneurial intentions: A meta-analytic review. Entrepreneurship Theory and Practice, 38(2), 217-254.

Bandura, A. (1977). Self-efficacy: Toward a unifying theory of behavioural change. Psychological Review, 84(2), 191-215.

Baron, R. M., \& Kenny, D. A. (1986). The moderator-mediator variable distinction in social psychological research: Conceptual, strategic, and statistical considerations. Journal of Personality and Social Psychology, 51(6), 1173-1182.

Baughn, C. C., \& Neupert, K. E. (2003). Culture and national conditions facilitating entrepreneurial start-ups. Journal of International Entrepreneurship, 1(3), 313-330.

Belás, J., Dvorský, J., Tyll, L., \& Zvaríková, K. (2017). Entrepreneurship of university students: Important factors and the propensity for entrepreneurship. Administration \& Public Management Review, 2018(28), 6-25.

Brockhaus, S. R. H. (1980). Risk taking propensity of entrepreneurs. Academy of Management Journal, 23(3), 509-520.

Bygrave, W. D., \& Hofer, C. W. (1992). Theorizing about entrepreneurship. Entrepreneurship theory and practice, 16(2), 13-22.

Carr, J. C., \& Sequeira, J. M. (2007). Prior family business exposure as intergenerational influence and entrepreneurial intent: A theory of planned behavior approach. Journal of Business Research, 60(10), 1090-1098.

Chipeta, E., \& Surujlal, J. (2017). Influence of attitude, risk taking propensity and proactive personality on social entrepreneurship intentions. Polish Journal of Management Studies, $5(2), 27-36$.

Choe, J.-m. (2004). The consideration of cultural differences in the design of information systems. Information \& Management, 41(5), 669-684.

Cromie, S. (2000). Assessing entrepreneurial inclinations: Some approaches and empirical evidence. European Journal of Work and Organizational Psychology, 9(1), 7-30.

Deshpande, V. (2018). Students' inclination towards social entrepreneurship with special reference to undergraduate students of a business school in Pune. International Research Journal of Multidisciplinary Studies, 4(2), 37-41.

Dunning, J. H., \& Kim, C. (2007). The cultural roots of Guanxi: An exploratory study. The World Economy, 30(2), 329-341.

Ekore, J. O., \& Okekeocha, O. C. (2012). Fear of entrepreneurship among university graduates: A psychological analysis. International Journal of Management, 29(2), 515-524. 
Fatoki, O. (2014). The entrepreneurial intention of undergraduate students in South Africa: The influences of entrepreneurship education and previous work experience. Mediterranean Journal of Social Sciences, 5(7), 294-299.

Franke, N., \& Lüthje, C. (2004). Entrepreneurial intentions of business students: A benchmarking study. International Journal of Innovation and Technology Management, 1(3), 269-288.

Garavan, T. N., \& O' Cinneide, B. (1994). Entrepreneurship education and training programmes: A review and evaluation-part 1. Journal of European industrial training, 18(8), 3-12.

Gelderen, M. v., Brand, M., Praag, M. v., Bodewes, W., Poutsma, E., \& Gils, A. v. (2008). Explaining entrepreneurial intentions by means of the theory of planned behaviour. Career Development International, 13(6), 538-559.

Gürol, Y., \& Atsan, N. (2006). Entrepreneurial characteristics amongst university students: Some insights for entrepreneurship education and training in Turkey. Education and Training, 48(1), 25-38.

Gwija, S. A., Chuks, E.-E., \& Chux, G. I. (2014). Challenges and prospects of youth entrepreneurship development in a designated community in the Western Cape, South Africa. Journal of Digital Knowledge, 1(2014), 10-20.

Hair, J. J., Black, W., Babin, B., Anderson, R., \& Tatham, R. (2010). SEM: An introduction. Multivariate data analysis: A global perspective, 629-686.

Haris, N., Yahya, Y., Abdullah, M., Othman, A., \& Rahman, F. (2016). A decision tree approach for predicting students entrepreneurial intention. Sindh University Research Journal-SURJ (Science Series), 48(4D), 45-50.

Hofstede, G. (2001). Cultural consequences. Sage Publications, Thousand Oaks, CA.

Hofstede, G., Bond, M. H., \& Luk, C.-1. (1993). Individual perceptions of organisational cultures: A methodological treatise on levels of analysis. Organisation Studies, 14(4), 483-503.

Hui, M. K., Au, K., \& Fock, H. (2004). Empowerment effects across cultures. Journal of International Business Studies, 35(1), 46-60.

Hyder, A., Azhar, A., Javaid, A., \& Rehman, M. (2011). Entrepreneurial intentions among business students in Pakistan. Journal of Business Systems, Governance and Ethics, 5(2), 13-21.

Jaw, B.-S., Ling, Y.-H., Yu-Ping Wang, C., \& Chang, W.-C. (2007). The impact of culture on Chinese employees' work values. Personnel Review, 36(1), 128-144.

Jung, J. M., \& Kellaris, J. J. (2004). Cross-national differences in proneness to scarcity effects: The moderating roles of familiarity, uncertainty avoidance, and need for cognitive closure. Psychology \& Marketing, 21(9), 739-753.

Juračak, J., \& Tica, M. (2016). Graduate students' opinions about entrepreneurship as an employment opportunity. Applied Studies in Agribusiness and Commerce, 10(1), 23-30.

Karimi, S., Biemans, H., Lans, T., Mulder, M., \& Chizari, M. (2012). The role of entrepreneurship education in developing students' entrepreneurial intentions. Proceedings of WICaNeM 2012, The 10th Wageningen international conference on chain and network science, Wageningen University, Wageningen,The Netherland, 22.

Keat, Y., \& Ahmad, S. (2012). A study among university students in business start-ups in Malaysia: Motivations and obstacles to become entrepreneurs. International Journal of Business and Social Science, 3(19), 181-192.

Klofsten, M. (2000). Training entrepreneurship at universities: A Swedish case. Journal of European Industrial Training, 24(6), 337-344.

Kolade, O. (2018). Venturing under fire: Entrepreneurship education, venture creation, and poverty reduction in conflict-ridden Maiduguri, Nigeria. Journal of Education and Training, 1(2018), 1-20.

Kuratko, D. F. (2009). Introduction to entrepreneurship: South-Western Australia and UK.

Leibenstein, H. (1968). Entrepreneurship and development. The American Economic Review, 58(2), $72-83$.

Linan, F. (2008). Skill and value perceptions: How do they affect entrepreneurial intentions? International Entrepreneurship and Management Journal, 4(3), 257-272. 
Low, M. B., \& MacMillan, I. C. (1988). Entrepreneurship: Past research and future challenges. Journal of Management, 14(2), 139-161.

Marques, C. S., Ferreira, J. J., Gomes, D. N., \& Gouveia Rodrigues, R. (2012). Entrepreneurship education: How psychological, demographic and behavioural factors predict the entrepreneurial intention. Education and Training, 54(8/9), 657-672.

Martin, S., \& Maabten, S. (1990). A case study of the effects of culture on economic development. .

Mueller, S. L., Thomas, A. S., \& Jaeger, A. M. (2002). National Entrepreneurial Potential: The Role of Culture, Economic Development, and Political History Advances in Comparative International Management (Vol. 14, pp. 221-257): Elsevier.

Mueller Susan. (2011). Increasing entrepreneurial intention: Effective entrepreneurship course characteristics. International Journal of Entrepreneurship and Small Business, 13(1), 55-74.

Mwiya, B. M. K. (2014). The impact of entrepreneurship education on the relationships between institutional and individual factors and entrepreneurial intention of university graduates: Evidence from Zambia.

Nasiru, A., Keat, O. Y., \& Bhatti, M. A. (2015). Influence of perceived university support, perceived effective entrepreneurship education, perceived creativity disposition, entrepreneurial passion for inventing and founding on entrepreneurial intention. Mediterranean Journal of Social Sciences, 6(3), 88-95.

Ndofirepi, T. M., \& Rambe, P. (2017). Entrepreneurship education and its impact on the entrepreneurship career intentions of vocational education students. Problems and Perspectives in Management, 15(1-1), 191-199.

Nielsen, S. L., \& Lassen, A. H. (2012). Identity in entrepreneurship effectuation theory: A supplementary framework. International Entrepreneurship and Management Journal, 8(3), 373-389.

Ojewumi, A. K., Oyeleke, J. T., Agberotimi, F., \& Adedayo, O. (2018). Obafemi Awolowo university undergraduate students: The influence of gender and self-efficacy on entrepreneurial intentions. Africology: The Journal of Pan African Studies, 11(2), 168-185.

Park, C. (2017). A study on effect of entrepreneurship on entrepreneurial intention: Focusing on ICT majors. Asia Pacific Journal of Innovation and Entrepreneurship, 11(2), 159-170.

Pennings, J. M., \& Curran, J. (1982). Organisational birth frequencies: An empirical investigation science quarterly. European Small Business Journal, 1(1), 92-92.

Ralston, D. A., Holt, D. H., Terpstra, R. H., \& Kai-Cheng, Y. (1997). The impact of natural culture and economic ideology on managerial work values: A study of the United States, Russia, Japan, and China. Journal of International Business Studies, 28(1), 177-207.

Rameseder, G. (2017). The roots of entrepreneurial career goals among today's engineering undergraduate students. Paper presented at the Proceedings of the American Society for Engineering Education Annual Conference, June 25-28. Columbus, $\mathrm{OH}$.

Rasul, O., Bekun, F. V., \& Saint Akadiri, S. (2017). The impact of self-efficacy on international student entrepreneur intention. International Review of Management and Marketing, 7(1), 169-174.

Raza, S. A., \& Irfan, M. (2017). Investigating the intentions, self-efficacy and motivators behind entrepreneurial decisions of business students. Bulletin of Education and Research, 39(3), 117-129.

Rothaermel, F. T., Agung, S. D., \& Jiang, L. (2007). University entrepreneurship: A taxonomy of the literature. Industrial and Corporate Change, 16(4), 691-791.

Saleh, W., \& Salhieh, L. (2014). An investigation of entrepreneurial intention amongst Arab university students. International Journal of Business and Management, 9(12), 197-209.

Sánchez, J. C. (2011). University training for entrepreneurial competencies: Its impact on intention of venture creation. International Entrepreneurship and Management Journal, 7(2), 239254.

Schaubroeck, J., Lam, S. S., \& Xie, J. L. (2000). Collective efficacy versus self-efficacy in coping responses to stressors and control: A cross-cultural study. Journal of Applied Psychology, $85(4), 512-525$. 
Schumpeter, J. (1934). The Schumpeter: Theory of economic development: Harvard University Press. Shane, S., \& Venkataraman, S. (2000). The promise of entrepreneurship as a field of research. Academy of Management Review, 25(1), 217-226.

Shirokova, G., Osiyevskyy, O., \& Bogatyreva, K. (2016). Exploring the intention-behaviour link in student entrepreneurship: Moderating effects of individual and environmental characteristics. European Management Journal, 34(4), 386-399.

Shneor, R., Metin Camgöz, S., \& Bayhan Karapinar, P. (2013). The interaction between culture and sex in the formation of entrepreneurial intentions. Entrepreneurship \& regional development, 25(9-10), 781-803.

Shook, C. L., \& Bratianu, C. (2010). Entrepreneurial intent in a transitional economy: An application of the theory of planned behaviour to Romanian students. International Entrepreneurship and Management Journal, 6(3), 231-247.

Singelis, T. M., Triandis, H. C., Bhawuk, D. P., \& Gelfand, M. J. (1995). Horizontal and vertical dimensions of individualism and collectivism: A theoretical and measurement refinement. Cross-Cultural Research, 29(3), 240-275.

Solesvik, M., Westhead, P., \& Matlay, H. (2014). Cultural factors and entrepreneurial intention: The role of entrepreneurship education. Education and Training, 56(8/9), 680-696.

Sotirakou, T. (2004). Coping with conflict within the entrepreneurial university: Threat or challenge for heads of departments in the UK higher education context. International Review of Administrative Sciences, 70(2), 345-372.

Stenholm, P., Acs, Z. J., \& Wuebker, R. (2013). Exploring country-level institutional arrangements on the rate and type of entrepreneurial activity. Journal of Business Venturing, 28(2013), 176-193.

Suffian, M., Rosman, M., Norlaila, I., Norizan, A., \& Hasnan, M. (2018). Entrepreneurial intention: An empirical study among undergraduate students. Journal of Fundamental and Applied Sciences, 10(2S), 413-435.

Turker, D., \& Sonmez Selçuk, S. (2009). Which factors affect entrepreneurial intention of university students? Journal of European Industrial Training, 33(2), 142-159.

Wang, W., Lu, W., \& Millington, J. K. (2011). Determinants of entrepreneurial intention among college students in China and USA. Journal of Global Entrepreneurship Research, 1(1), 3544.

Yoo, B., Donthu, N., \& Lenartowicz, T. (2011). Measuring Hofstede's five dimensions of cultural values at the individual level: Development and validation of CVSCALE. Journal of International Consumer Marketing, 23(3-4), 193-210.

Yoon, C. (2009). The effects of national culture values on consumer acceptance of e-commerce: Online shoppers in China. Information \& Management, 46(5), 294-301. 